\title{
Poly(3-hydroxybutyrate-co-4-hydroxybutyrate) Produced by Delfitia acidovorans in Different Cell-Concentration and Fed-Batch Cultures
}

\author{
Wen-chuan Hsieh*, Yuki Wada, and Hiroshi Mitomo
}

\author{
Department of Biological Chemical Engineering, Faculty of Engineering, Gunma University, 1-5-1 \\ Tenjin-cho, Kiryu, Gunma 376-8515, Japan
}

\begin{abstract}
Delftia acidovorans (IFO13582) was grown in fed-batch and chemostat cultures with $n$-butyric acid and 1,4-butanediol as mixed carbon substrates. In fed-batch cultures, the synthesis rate of the polymer was considerably increased with the increment of the cell growth. The polymer content increased and reached to a maximum of $27 \mathrm{wt} \%$ with increasing the cell dry-weight of ca. 4.4-5.2 $\mathrm{g} / \mathrm{l}$ at $26^{\circ} \mathrm{C}$ for $72 \mathrm{~h}$ and the maximum $4 \mathrm{HB}$ unit composition of poly(3-hydroxybutyrate-co-4-hydroxybutyrate) [P(3HB-co-4HB)] was slightly low value of ca. 66 mol\%. Whereas the maximum $4 \mathrm{HB}$ unit composition of $\mathrm{P}(3 \mathrm{HB}-\mathrm{co}-4 \mathrm{HB})$ obtained by the fed-batch culture with lower cell concentration of ca. $2.5 \mathrm{~g} / \mathrm{l}$ reached to $94 \mathrm{~mol} \%$ though the content of $\mathrm{P}(3 \mathrm{HB}-\mathrm{co}-4 \mathrm{HB})$ was always low, at ca. $13 \mathrm{wt} \%$.
\end{abstract}

(Received 24 July, 2003; Accepted 28 October, 2003)

\section{Introduction}

Aliphatic polyesters and their copolymers, i.e., poly(3-hydroxybutyrate) $[\mathrm{P}(3 \mathrm{HB})]$, poly $(3-$ hydroxybutyrate-co-3-hydroxyvalerate) $[\mathrm{P}(3 \mathrm{HB}-\mathrm{co}-3 \mathrm{HV})]$ and poly(3-hydroxybutyrate-co-4-hydroxybutyrate) [P(3HBco-4HB)], etc. are biocompatible and biodegradable thermoplastic polymer materials produced in nature by various kinds of bacteria as an intracellular carbon and energy source [1-3]. In practice, biodegradable polymers have not been issues of environmental pollution, but these green polymers have not been widely and commercially exploited, because their price is considerably higher than that of traditional plastics. The development of industrial fermentation that permits a high productivity of the polymers is most important for reducing the production costs.

It is considered that the cultural conditions exert a significant influence on the biosynthesis reaction by microorganisms [3-8]. The main cultural factors were as follows: medium composition, concentration of carbon source, $\mathrm{pH}$, incubation temperature, time, cell concentration, quantity of supply oxygen, and so on. Kimura et al. [9] has been reported that the dry cell weight obtained and polymers produced significantly changed in fermentation by Delftia acidovorans with addition of $\mathrm{CaCl}_{2}$ and $\mathrm{MgSO}_{4}$ in the medium

\footnotetext{
* Corresponding author. Present address: Department of Chemical System Engineering, School of Engineering, The University of Tokyo, 7-3-1 Hongo, Bunkyo-ku, Tokyo 113-8656, Japan

Tel \& Fax:+81-3-5841-7363

E-mail: wenchuan@chymsys.t.u-tokyo.ac.jp
}

composition. We have been reported on the production of $\mathrm{P}(3 \mathrm{HB}-\mathrm{co-3HV})$ by Burkholderia cepacia D1 using $n$-butyric acid and $n$-valeric acid as the carbon sources [10]. It was found that at the second-step fermentation, the yield of polymers strongly depend on the concentrations of the cell and carbon sources.

In a previous paper [11], we observed the influence of the $\mathrm{pH}$, incubation temperature, incubation time and carbon source concentration on the biosynthesis of $\mathrm{P}(3 \mathrm{HB}-\mathrm{co}-4 \mathrm{HB})$ polymer. In addition, production of the polymer by $D$. acidovorans from mixed carbon sources of $n$-butyric acid and 1,4-butanediol, whose prices are relatively cheaper than other organic substrates, was reported. The most optimum conditions experimentally determined were as follows: $\mathrm{pH}, 7.0$; Incubation temperature, $26{ }^{\circ} \mathrm{C}$; Incubation time, $72 \mathrm{~h}$; and concentration of carbon sources, $10 \mathrm{~g} / \mathrm{l}$.

The $D$. acidovorans isolated from sewage sludge can produce $\mathrm{P}(3 \mathrm{HB})$ and $\mathrm{P}(3 \mathrm{HB}-\mathrm{co}-3 \mathrm{HV})$ or $\mathrm{P}(3 \mathrm{HB}-\mathrm{co}-4 \mathrm{HB})$ having various compositions if supplied different kind and ratio of carbon sources. In addition, $D$. acidovorans can produce a terpolyester of $3 \mathrm{HB}, 4 \mathrm{HB}$ and $3 \mathrm{HV}$ from the mixed carbon substrates [5-8].

In this study, the effect of cell concentration on the production of the polymers $\mathrm{P}(3 \mathrm{HB})$ and $\mathrm{P}(3 \mathrm{HB}-c o-4 \mathrm{HB})$ by $D$. acidovorans was examined. The width of composition range and polymer content of $\mathrm{P}(3 \mathrm{HB}-\mathrm{co}-4 \mathrm{HB})$ copolymer produced by $D$. acidovorans supplied mixed carbon sources of $n$-butyric acid and 1,4-butanediol is discussed against different cell concentrations of the culture.

\section{Experimental}

\subsection{Biopolymer synthesis}


The strain used was Delftia acidovorans (IFO13582). P(3HB-co-4HB) synthesis was carried out by a two step cultivation. $D$. acidovorans was grown under aeration at $26^{\circ} \mathrm{C}$ in a nutrient-rich medium $(100$ $\mathrm{m} l$ ) containing $1 \mathrm{~g}$ polypetone, $1 \mathrm{~g}$ yeast extract, $0.5 \mathrm{~g}$ meat extract, and $0.5 \mathrm{~g}\left(\mathrm{NH}_{4}\right)_{2} \mathrm{SO}_{4}$ [7]. To promote the polyester synthesis, the bacterial cells were transferred into a nitrogen-free medium containing $n$-butyric acid and 1,4-butanediol as the carbon sources [11]. $\mathrm{P}(3 \mathrm{HB}-\mathrm{co}-4 \mathrm{HB}) \mathrm{s}$ of different composition were biosynthesized by $D$. acidovorans grown in different ration of the carbon sources. The medium [8] contained the following (per liter): $7.16 \mathrm{~g} \mathrm{Na}_{2} \mathrm{HPO}_{4} \cdot 12 \mathrm{H}_{2} \mathrm{O} ; 2.65 \mathrm{~g}$ $\mathrm{KH}_{2} \mathrm{PO}_{4} ; 0.2 \mathrm{~g} \mathrm{MgSO}_{4} \cdot 7 \mathrm{H}_{2} \mathrm{O} ; 0.1 \mathrm{~g}\left(\mathrm{NH}_{4}\right)_{2} \mathrm{SO}_{4} ; 1 \mathrm{~g} \mathrm{CaCl}$ - $2 \mathrm{H}_{2} \mathrm{O} ; 5 \mathrm{~g}$ citric acid; and $1 \mathrm{ml}$ microelement solution. The microelement solution contained the following (per liter): $0.217 \mathrm{~g} \mathrm{CoCl} 2 \cdot 6 \mathrm{H}_{2} \mathrm{O} ; 0.0162 \mathrm{~g} \mathrm{FeCl} \cdot 6 \mathrm{H}_{2} \mathrm{O}$; $0.0078 \mathrm{~g} \mathrm{CaCl}_{2} \cdot 2 \mathrm{H}_{2} \mathrm{O} ; 0.118 \mathrm{~g} \mathrm{NiCl}_{2} \cdot 6 \mathrm{H}_{2} \mathrm{O} ; 0.135 \mathrm{~g} \mathrm{CrCl}_{3}$ - $6 \mathrm{H}_{2} \mathrm{O} ; 0.156 \mathrm{~g} \mathrm{CuSO}_{4} \cdot 5 \mathrm{H}_{2} \mathrm{O}$; in an aqueous solution of $0.1 \mathrm{~N} \mathrm{HCl}$. The cells were incubated in these media at $26^{\circ} \mathrm{C}$ for $72 \mathrm{~h}$, harvested by centrifugation, washed with methanol and finally dried. The polyester was extracted

Table 1 Production of $\mathrm{P}(3 \mathrm{HB}-\mathrm{co}-4 \mathrm{HB})$ by Delftia acidovorans at $26^{\circ} \mathrm{C}$ grown on various ratios of two carbon sources.

\begin{tabular}{|c|c|c|c|c|c|c|}
\hline \multirow[t]{2}{*}{$\begin{array}{l}\text { Run } \\
\text { no. }\end{array}$} & \multirow{2}{*}{$\begin{array}{l}\text { Cell dry } \\
\text { weight } \\
(\mathrm{g} / \mathrm{l})\end{array}$} & \multicolumn{2}{|c|}{$\begin{array}{c}\text { Carbon sources } \\
(\mathrm{g} / \mathrm{l})\end{array}$} & \multirow{2}{*}{$\begin{array}{c}\text { Polyester } \\
\text { content } \\
(w t \%)\end{array}$} & \multicolumn{2}{|c|}{$\begin{array}{c}\text { PHA composition } \\
(\mathrm{mol} \%)\end{array}$} \\
\hline & & $n$-Butyric acid & 1,4-Butanediol & & $3 \mathrm{HB}$ & $4 \mathrm{HB}$ \\
\hline 1 & 2.6 & 10 & 0 & 14 & 100 & 0 \\
\hline 2 & 2.4 & 8 & 2 & 8 & 81 & 19 \\
\hline 3 & 2.6 & 7 & 3 & 13 & 73 & 30 \\
\hline 4 & 2.7 & 6 & 4 & 15 & 62 & 38 \\
\hline 5 & 2.2 & 5 & 5 & 14 & 53 & 45 \\
\hline 6 & 2.5 & 4 & 6 & 13 & 35 & 65 \\
\hline 7 & 2.8 & 2 & 8 & 11 & 26 & 74 \\
\hline 8 & 2.5 & 0 & 10 & 13 & 6 & 94 \\
\hline 9 & 4.8 & 10 & 0 & 24 & 100 & 0 \\
\hline 10 & 5.0 & 8 & 2 & 26 & 95 & 5 \\
\hline 11 & 5.1 & 7 & 3 & 24 & 92 & 8 \\
\hline 12 & 4.8 & 6 & 4 & 25 & 88 & 12 \\
\hline 13 & 5.2 & 5 & 5 & 27 & 83 & 17 \\
\hline 14 & 4.7 & 4 & 6 & 26 & 79 & 21 \\
\hline 15 & 4.9 & 2 & 8 & 21 & 68 & 32 \\
\hline 16 & 4.4 & 0 & 10 & 10 & 34 & 66 \\
\hline 17 & 6.1 & 10 & 0 & 19 & 100 & 0 \\
\hline 18 & 5.8 & 8 & 2 & 17 & 97 & 3 \\
\hline 19 & 6.0 & 7 & 3 & 18 & 94 & 6 \\
\hline 20 & 6.5 & 6 & 4 & 16 & 89 & 15 \\
\hline 21 & 6.3 & 5 & 5 & 13 & 74 & 26 \\
\hline 22 & 6.5 & 4 & 6 & 15 & 65 & 35 \\
\hline 23 & 6.4 & 2 & 8 & 18 & 53 & 47 \\
\hline 24 & 5.7 & 0 & 10 & 11 & 29 & 71 \\
\hline
\end{tabular}

a. Determined by ${ }^{1} \mathrm{H}-\mathrm{NMR}$. 
from the dried cells with hot chloroform, purified by precipitation with hexane, dried under vacuum and used for the analysis. The polymer content was measured as follows:

$$
\text { Polymer content }(w t \%)=(W a-W b) \times 100
$$

where $\mathrm{Wa}$ is the polymer weight $(\mathrm{g})$ and $\mathrm{Wb}$ is the cell dry-weight $(\mathrm{g})$.

\subsection{Analytical procedures}

The compositions of the $\mathrm{P}(3 \mathrm{HB}-\mathrm{co}-4 \mathrm{HB})$ samples were determined using a JEOL $\alpha-500$ spectrometer. The $500 \mathrm{MHz}{ }^{1} \mathrm{H}-\mathrm{NMR}$ spectra were recorded at room temperature for a $\mathrm{CDCl}_{3}$ solution of $\mathrm{P}(3 \mathrm{HB}-c o-4 \mathrm{HB})$ with a $4.7 \mu$ s pulse width, 5 -s pulse repetition, $5000 \mathrm{~Hz}$ spectral width, $16 \mathrm{~K}$ data points and 32 accumulations. Tetramethylsilane $\left(\mathrm{Me}_{4} \mathrm{Si}, \delta=0\right)$ was used as the internal chemical shift standard.

\section{Results and discussion}

3.1 Effect of 1,4-butanedion/n-butyric acid balance and the cell concentration on the productivity of the polymer

Seed cultures were first grown on a reciprocal shaker in $500 \mathrm{ml}$ Sakaguchi flasks and then transferred to inoculate $10 l$ fermentor. The working volume of the culture was $5 l$ in all the fed-batch experiments done in this study. Table 1 list the results of the production of $\mathrm{P}(3 \mathrm{HB}-\mathrm{co}-4 \mathrm{HB})$ from cells of $D$. acidovorans grown on mixed substrates of $n$-butyric acid and 1,4-butanediol in a two-step fermentation. The cultural conditions, e.g., control of $\mathrm{pH}$, incubation temperature, time, and concentration of the carbon sources corresponded to those in a previous paper [11]. In order to elucidate the relation of the cell concentration and polymer content, the cell dry-weight was controlled at ca. $2.5,5$ and $6 \mathrm{~g}$, and harvested after the second-step fermentation. The multiplying of cell growth was carried out at 2, 4 and $5 l$ in Sakaguchi flasks at the first stage, respectively. The compositions of the $\mathrm{P}(3 \mathrm{HB}-c o-4 \mathrm{HB})$ samples were determined by ${ }^{1} \mathrm{H}-\mathrm{NMR}$. The composition of both components could be estimated from the areas under peak $\mathrm{CH}$ of $3 \mathrm{HB}$ and peak $\mathrm{CH}_{2}$ of $4 \mathrm{HB}$ by ${ }^{1} \mathrm{H}$-NMR that was reported in the previous papers [11, 12].

Fig. 1 shows the plot of the cell dry-weight and polymer content versus 1,4-butanediol in the feed. The cell dry-weight was controlled at ca. $2.5 \mathrm{~g}(\mathbf{\square})$, and the polymer content was around $13 \mathrm{wt} \%$. It was lower than that of Ralstonia eutropha [13] or Alcaligenes latus [14]. When the cell concentration increased from $2.4-2.7 \mathrm{~g}$ (घ) to $4.4-5.2 \mathrm{~g} \mathrm{( \Delta )}$, the polymer content increased from ca. $13 \mathrm{wt} \%$ to around $27 \mathrm{wt} \%$. On the other hand, when the cell concentration increased to 5.7-6.5g $(\mathrm{O})$, and the polymer content was inversely reduced to ca. $15 \mathrm{wt} \%$. For cell concentration of above $6 \mathrm{~g}(\mathrm{O})$, the polymer content was significantly reduced than that of $5 \mathrm{~g}(\mathbf{\Delta})$ due to the fact that the cellular concentration may be too high to promote the polymer production by microorganisms in the $5 l$ cultural medium. It is implied that the polymer content was strongly influenced by the cell concentration.

Furthermore, when the production of $\mathrm{P}(3 \mathrm{HB}-c o-4 \mathrm{HB})$ by $D$. acidovorans used 1,4-butanediol as a sole carbon source, the polymer content tended to have a low yield. The carbon source of 1,4-butanediol can be directly converted into 4-hydroxybutyric acid, exhibiting a distinctive metabolism in comparison with $n$-butyric acid [15]. Considering the polymer content depending on the mixed carbon substrates supplied in the feed, consequently, the polymer yield of fermentation using sole carbon source of 1,4-butanediol is lower than the yield using the mixed carbon source in the cellular metabolism converted into the polymer. The similar results were also reported in the previous papers $[3,8,10,13,16,17]$. The optimum concentration of the cell is around $5 \mathrm{~g}$ in this study, where the highest polymer content was around $27 \mathrm{wt} \%$.

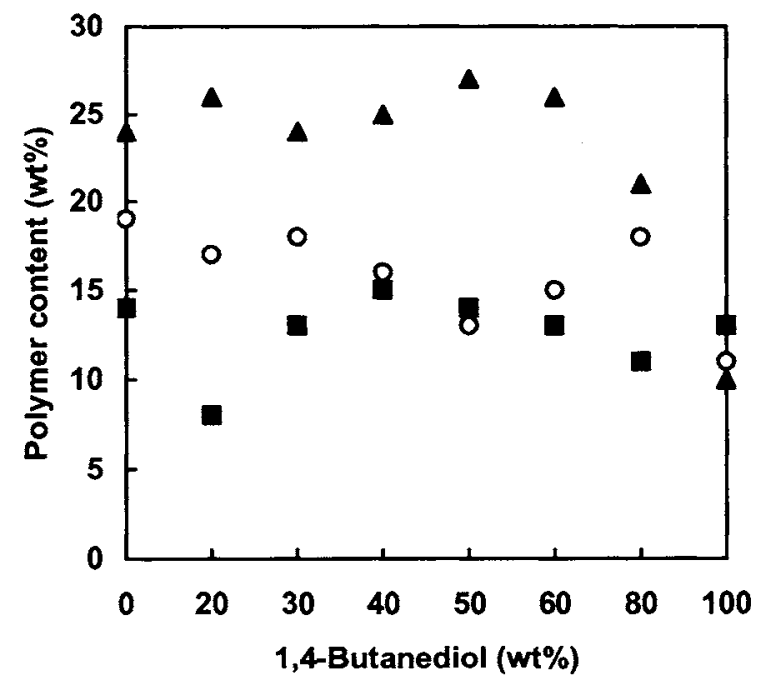

Fig. 1 A plot of polymer content versus 1,4-butanediol in feed. (the cell dry-weights are $\mathbf{\square}: 2.5 \mathrm{~g} ; \boldsymbol{\Delta}: 5 \mathrm{~g}$; and $\bigcirc: 6 \mathrm{~g}$.)

\subsection{Effect of 1,4-butanediol ratio and the cell concentration on the composition of the polymer}

Fig. 2 shows plots of the composition of the $4 \mathrm{HB}$ component determined by ${ }^{~} \mathrm{H}-\mathrm{NMR}$ of $\mathrm{P}(3 \mathrm{HB}-c o-4 \mathrm{HB})$ versus the content of 1,4-butanediol in the feed. When the cell dry-weight was controlled at ca. $2.5 \mathrm{~g} / l$, the $4 \mathrm{HB}$ contents linearly increased from 0 to $94 \mathrm{~mol} \%$ ( $\boldsymbol{\square}$ ) as the content of 1,4-butanediol increased from 0 to $100 \%$, which mines that the $4 \mathrm{HB}$ content in the copolymer was closely identical to the content of 1,4-butanediol in the feed. A similar result was reported for $\mathrm{P}(3 \mathrm{HB}-\mathrm{co}-4 \mathrm{HB})$ obtained from the mixed carbon sources of 3-hydroxybutyrate and 4-hydroxybutyrate by $A$. latus 
[18]. Further, the P(3HB-co-96mol\% 4HB) was obtained from the sole carbon source of 1,4-butanediol by $D$. acidovorans [7] for $72 \mathrm{~h}$, and $\mathrm{P}(3 \mathrm{HB}-\mathrm{co}-99 \mathrm{~mol} \% 4 \mathrm{HB})$ was obtained after a longer incubation time.

When the cell dry-weight increased to ca. $5 \mathrm{~g}(\boldsymbol{\Delta})$ or $6 \mathrm{~g}(\mathrm{O})$, the composition range of $4 \mathrm{HB}$ component in the copolymer appeared at lower range than that obtained using ca. $2.5 \mathrm{~g}(\boldsymbol{\square})$ of the cell dry-weight. It can be considered that the cell concentration significantly affected the composition of $\mathrm{P}(3 \mathrm{HB}-\mathrm{co}-4 \mathrm{HB})$ in the all range of $4 \mathrm{HB}$ component.

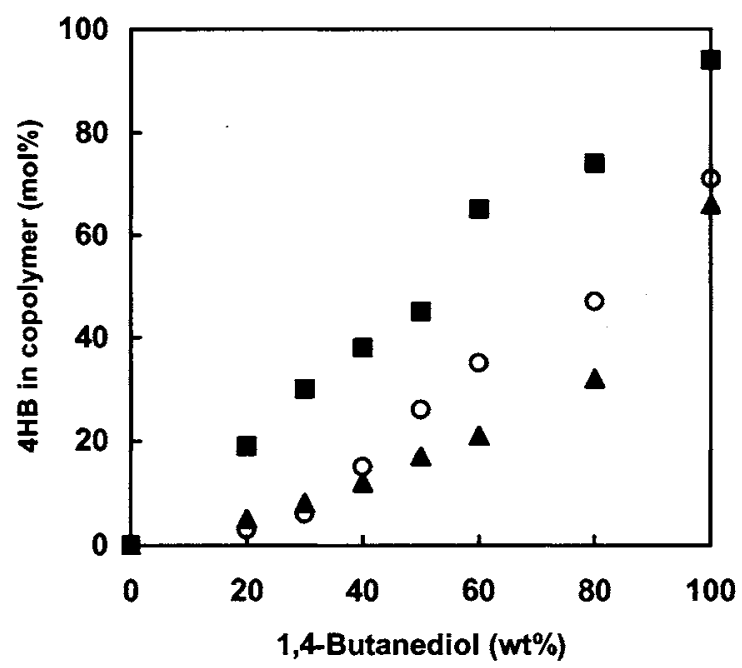

Fig. 2 Relation between composition of the 4HB component in copolymer and 1,4-butanediol in carbon sources. (the cell dry-weights are $2.5 \mathrm{~g} ; \mathbf{\Lambda}: 5 \mathrm{~g}$; and $\mathrm{O}: 6 \mathrm{~g}$.)

It is well-known that the $\mathrm{P}(3 \mathrm{HB})$ can be intracellularly biosynthesized by condensation from sugars and/or organic acids by synthase of 3-hydroxybutyryl-coenzyme A, formed from acetyl-CoA via acetoacetyl-CoA and butyryl-CoA, respectively [15]. If 1,4-butanediol was used as the sole carbon source, 4-hydroxybutyryl-CoA may be intracellularly formed via a hydrolysis step or converted into acetoacetyl-CoA via an oxidation step to the TCA cycle. Furthermore, a portion of 1,4-butanediol may be converted into 3-hydroxybutyryl-CoA via vinylacetyl-CoA to form the $3 \mathrm{HB}$ units. This is one reason that the $\mathrm{P}(4 \mathrm{HB})$ homopolymer can't be obtained in this study.

\section{References}

1. P. A. Holmes, Phys. Technol., 16, 32 (1985).

2. M. Liebergesell, E. Hustede, A. Timm, A, Steinbuchel, R. C. Fuller, R. W. Lenz, and H. G. Schlegel, Arch. Microbiol., 155, 415 (1991).

3. Y. Doi, A. Segawa, and M. Kunioka, Int. J. Biol. Macromol., 12, 106 (1990).

4. K. Hori, K. Soga, and Y. Doi, Biotechnol. Lett., 16, 709(1984).

5. Y. Saito, S. Nakamura, M. Hiramitsu, and Y. Doi, Polym. Int., 39, 169 (1996).

6. Y. Saito and Y. Doi, Biodegradable Plastics and Polymer, ed. Y. Doi and K. Fukuda, Elsevier Science P.394 (1994).

7. H. Kimura, Y. Yoshida, and Y. Doi, Biotechnol. Lett., 14, 445 (1992).

8. Y. Saito and Y. Doi, Int. J. Biol. Macromol., 16, 99 (1994).

9. H. Kimura, F. Knodo, M. Takeishi, and Y. Doi, Sen-I Gakkai Preprints, P-22, (1995).

10. H. Mitomo, T. Takahashi, H. Ito, and T. Saito, Int. J. Biol. Micromol., 24, 311(1999).

11. H. Mitomo, W. -C. Hsieh, K. Nishiwaki, K. Kasuya, and Y. Doi, Polymer, 42, 3455(2001).

12. W. -C. Hsieh, K. Nishiwaki, N. Tanaka, and H. Mitomo, Sen-I Gakkaishi, 58, 98(2002).

13. M. Kunioka, Y. Nakamura, and Y. Doi, Polym. Commum., 29, 174(1988).

14. M. Hiramitsu, N. Koyama, and Y. Doi, Biotechnol. Lett., 15, 461(1993).

15. Y. Doi, Microbial polyesters, New York: VCH, 1990.

16. A. Cao, K. Kasuya, H. Abe, Y. Doi, and Y. Inoue, Polymer, 39, 4801(1998).

17. M. Kunioka, Y. kawaguchi, and Y. Doi, Appl. Microbiol, Biotechnol., 30, 569(1989).

18. C. -K. Kang, S. Kusaka, and Y. Doi, Biotechnol. Lett., 17, 583(1995). 